DOI https://doi.org/10.18551/rjoas.2020-11.04

\title{
THE BLUE ECONOMY: A SOLUTION TO THE DOWNFALL OF BALI TOURISM
}

Putra I G.B.N.P.*, Larasdiputra G.D.

Faculty of Economics and Business, University of Warmadewa, Indonesia

*E-mail: ngurahpanji.putra@gmail.com

\begin{abstract}
The purpose of this research is to find out the concept of The Blue Economy as an alternative solution for income sources for the community when turmoil occurs in the tourism sector in Bali. Researchers used literature study methods. The data obtained will be analyzed using qualitative descriptive analysis techniques. The results of this study are expected to be able to contribute ideas or references for decision makers, in this case the Bali Provincial Government in the context of implementing the concept of The Blue Economy as an alternative source of income solution for the community when turmoil occurs in the tourism sector in Bali. The result show that the kind of The Blue Economy Concept that can apply in Bali according to this research are 1) An Export Crop that Creates Food Security and 2) Integration of Aquaculture into Farming Activities.
\end{abstract}

\section{KEY WORDS}

The Blue Economy, COVID-19, tourism, economy.

Bali, one of the best tourist destinations in the world, has various tourist attractions. Millions of travelers from all over the world come to Bali every year. Based on data that researchers obtained from the Bali Province Central Bureau of Statistics, it is known that the number of foreign tourists visiting Bali has always increased over the last 10 (ten) years. This data is certainly not surprising considering the island of Bali is always included in the top 5 (five) best tourism destinations in the world based on Tripadvisor. The travel planning and booking site has even named Bali as the number 1 tourism destination in the world in 2018.

Table 1 - Number of Foreign Tourist Visits to Bali Over the Last 10 Years

\begin{tabular}{|c|c|c|c|c|c|c|c|c|c|c|c|}
\hline Bulan & 2010 & 2011 & 2012 & 2013 & 2014 & 2015 & 2016 & 2017 & 2018 & 2019 & 2020 \\
\hline Januari & 179.273 & 209.093 & 253.286 & 232.935 & 279.257 & 301.748 & 350.592 & 460.824 & 358.065 & 455.570 & 528.883 \\
\hline Februari & 191.926 & 207.195 & 225.993 & 241.868 & 275.795 & 338.991 & 375.744 & 453.985 & 452.423 & 437.456 & 363.937 \\
\hline Maret & 192.579 & 207.907 & 230.957 & 252.210 & 276.573 & 305.272 & 364.113 & 425.499 & 492.678 & 449.569 & \\
\hline April & 184.907 & 224.704 & 225.488 & 242.369 & 280.096 & 313.763 & 380.767 & 477.464 & 516.777 & 477.069 & \\
\hline Mei & 203.388 & 209.058 & 220.700 & 247.972 & 286.033 & 295.973 & 394.557 & 489.376 & 528.512 & 486.602 & \\
\hline Juni & 228.045 & 245.652 & 244.080 & 275.667 & 330.396 & 359.702 & 405.835 & 504.141 & 544.550 & 549.516 & \\
\hline Juli & 254.907 & 283.524 & 271.512 & 297.878 & 361.066 & 382.683 & 484.231 & 592.046 & 624.366 & 604.323 & \\
\hline Agustus & 243.154 & 258.377 & 254.079 & 309.219 & 336.763 & 303.621 & 438.135 & 601.884 & 573.766 & 606.412 & \\
\hline September & 240.947 & 258.440 & 257.363 & 305.629 & 354.762 & 389.060 & 445.716 & 550.520 & 555.903 & 590.398 & \\
\hline Oktober & 229.904 & 247.565 & 255.021 & 266.562 & 341.651 & 369.447 & 432.215 & 465.085 & 517.889 & 567.967 & \\
\hline November & 199.861 & 221.603 & 242.781 & 307.276 & 296.876 & 270.935 & 413.232 & 361.006 & 406.725 & 497.925 & \\
\hline Desember & 227.251 & 253.591 & 268.072 & 299.013 & 347.370 & 370.640 & 442.800 & 315.909 & 498.819 & 552.403 & \\
\hline Jumlah/Total : & 2.576 .142 & 2.826 .709 & 2.949 .332 & 3.278 .598 & 3.766 .638 & 4.001 .835 & \begin{tabular}{|l|l|}
4.927 .937 \\
\end{tabular} & 5.697 .739 & 6.070 .473 & 6.275 .210 & 892.820 \\
\hline Pertumhuhan & 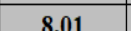 & 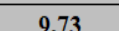 & 434 & 1116 & 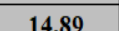 & 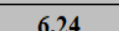 & & & & & \\
\hline
\end{tabular}

Source: Badan Pusat Statistik Provinsi Bali, 2020.

For decades, the tourism sector has become one of the pillars of the Balinese economy. However, it must be remembered that anything excessive is not good, including the dependence of the economy of Bali Province on one sector, namely the tourism sector. If the tourism sector is shaken, the majority of the Balinese economy will feel the impact. The tourism sector is very vulnerable to being shaken by acts of terrorism, natural disasters and disease outbreaks. The island of Bali was hit by terrorist acts in 2002 (Bali Bombing 1) and 2005 (Bali Bombing 2). Apart from acts of terrorism, the people of Bali certainly still 
remember the natural disaster of the eruption of Mount Agung at the end of 2017 which had brought the Bali economy to a standstill (balipost.com).

The reality that happened after the terrorism act and the natural disaster of the eruption of Mount Agung was that the economy had recovered and rose again. The effects of these two incidents were forgotten. There has been no new breakthrough to organize Bali's economic sector and keep it running by relying on the tourism sector. As mentioned above, the tourism sector is very vulnerable to being shaken by acts of terrorism, natural disasters, and disease outbreaks. Sure enough, the tourism sector was put to the test once again. Not just Bali, but the whole world. At the end of 2019, Corona Virus Disease 2019 (Covid-19) or better known as the Corona Virus began to spread in Wuhan City, Hubei Province, China. Covid-19 is a terrible terror for the world community because of its rapid spread. The most worrying thing is that until now a vaccine for Covid-19 has not yet been found, while the number of infected patients continues to increase every day. The World Health Organization (WHO) has even increased the status of the Covid-19 Virus case to a pandemic.

The island of Bali, which is the belle of tourism, is in fact one of the most vulnerable and risky areas. The massive number of tourist visits from all over the world has also brought negative things to Bali. The tourism sector, which is the gateway for the entry and exit of tourists, ideally has a filter that is able to filter out negative things from entering. However, in reality the ideal conditions are still far from expectations. On March 10, 2020, the Covid-19 case was first discovered in Bali Province (tirto.id). Until May 7, 2020, the number of positive patients with Covid-19 has even reached 287 people. Casualties have fallen, the economy of Bali has been shaken and the sector that has suffered the most is the tourism sector.

The fall in the number of tourist visits for the umpteenth time should be a trigger that Bali must clean up. It is time for Bali to prepare alternative sectors that support the economy apart from the tourism sector, so that what is called economic security can be realized. Community empowerment that leads to the MSME sector, especially the home industry, can be a solution. The Blue Economy (Blue Economy) is an interesting concept for researchers to study more deeply. The concept of The Blue Economy is described as an environmentally friendly business activity based on the way nature works and utilizing existing resources, while emphasizing efficiency.

The majority of previous studies have examined the application of the Blue Economy Concept to the marine sector only. But in truth, Prof. Dr. Gunter Pauli as the founder of the concept of The Blue Economy emphasizes that this concept does not depend on just one sector, but a combination of various sectors so as to create wider employment opportunities for the community. Considering that Indonesia is well-known as a "Maritime Country" and also a "Land of Agriculture", this study examines the implementation of the Blue Economy Concept in a broader scope, namely not only in the marine sector but also a combination of the agricultural, fishery, marine and animal husbandry which will eventually manifest in the form of small businesses (UMKM) on a home industry scale. That is the gap that will be filled in this study as well as the difference between this research and previous studies. The reason this research focuses more on small businesses (MSMEs) on a home industry scale is to make the concept of The Blue Economy easier to implement by all levels of society.

Researchers certainly hope that this concept can be applied in Bali considering that many people have lost their livelihoods when the tourism sector is shaken, such as when the Covid-19 outbreak hit. The concept of The Blue Economy is able to offer a sustainable solution, which is to create multiple effects or multiple effects that can move many sectors when the negative domino effect is actually caused by the Covid-19 pandemic. The implementation of the concept of The Blue Economy can create a chain impact on the development of businesses that rely on marine resources and the natural environment. Thus, the lofty aspirations contained in Indonesia's development planning for the welfare of the people can be realized through the concept of The Blue Economy.

In January 2020, the Governor of Bali, Wayan Koster, initiated an economic plan known as strengthening the fundamentals of the Balinese economy, by re-developing the agricultural sector. Researchers see that this is the right momentum to implement the concept of The Blue Economy by promoting the agricultural sector as well as the marine and 
fisheries sector. This background encourages researchers to conduct research related to the concept of The Blue Economy as an alternative source of income solution for the community when turmoil occurs in the tourism sector in Bali.

\section{LITERATURE REVIEW}

The Blue Economy Concept. The concept of The Blue Economy was first put forward by Prof. Dr. Gunter Pauli in his book entitled The Blue Economy, 10 Years, 100 Innovations, 100 Million Jobs, which describes the potential benefits of his theory for environmental protection of the world's community, preservation of natural resources, initiatives to reduce industrial costs by shifting to green, clean energy consumption., recycled or renewable products. The essence of blue economy according to Pauli (2006) is:

- Learn from Nature. The Blue Economy emulates nature, namely how ecosystems work in accordance with what nature provides and how to work with high efficiency.

- Ecosystem Logic. The way the ecosystem works is used as a model for The Blue Economy, which is like water flowing from a mountain carrying nutrients and energy to meet the basic needs of all living things and plants that interact and provide for each other - waste from something to become food / energy for others. Only by gravity is energy distributed efficiently and evenly without stopping and without external energy extraction.

- Innovation and Creativity. The Blue Economy thrives on innovation and creativity. There are 100 practical economic innovations that have inspired The Blue Economy with the principle of emulating how ecosystems work: ecosystems are always working towards higher levels of efficiency to deliver nutrients and energy without waste to meet the basic needs of all contributors in a system.

According to IIma (2014), The Blue Economy is a process where the raw materials and production processes come from the universe and follow the way nature works. Quoted from Rani and Cahyasari (2015), it is stated that the blue economy is a model of economic development that unites sea and land development, emphasizing optimizing the use of technology, industry, land and marine waters, in order to increase the overall level of utilization of marine resources. Satria (2012) states that in a blue economy, high innovation and creativity are required to be able to find natural cycles which then become an inspiration for a clean local economic activity. The innovation and creativity that is created will have implications for local independence. According to Nurhayati (2013), Indonesia's marine resources are the foundation of many people who have livelihoods in the fisheries and marine sector such as fishermen, fish processors, marine tourism managers and their derivative businesses such as travel agents, lodging, souvenir traders, and so on. . The huge marine potential requires careful planning by regions that have marine areas. Technically, especially in marine and coastal development, it is hoped that it can be based on a development strategy based on The Blue Economy or Blue Economy (Saksono, 2013).

In accordance with the above explanation and the slogan "Blue Sky-Blue Ocean", the concept of The Blue Economy can be applied to the fisheries and marine sectors. This was studied in the research conducted by Rani and Cahyasari (2015) on "Indonesia's Motivation in Implementing The Blue Economy Policy Model during the Joko Widodo Administration". The results of this study explain that the side-by-side application of the Blue Economy model in Indonesia's development planning has a positive impact on the preservation of fisheries and marine resources and the environment. Similar research was conducted by Zamroni, et al. (2018) who examined the opportunities for applying the concept of The Blue Economy to fisheries business in East Lombok Regency. The results of the review show that 6 (six) fishery businesses can provide multiple effects, namely lobster cultivation, seaweed cultivation, crab processing, fish head waste processing, and salt ponds which have the opportunity to create multiple effects, meaning that the six businesses can create alternative livelihoods can have an impact on improving the household economy.

The Blue Economy vs Green Economy. In the past few years, we were still talking about Indonesia's development planning that was oriented towards a green economy, then 
what was the connection with The Blue Economy. The concept of The Blue Economy is one thing that will support the running of the green economy concept which has been a concept in Indonesia's development planning. The definition of a green economy in simple terms can be defined as an economy that is low carbon (does not produce emissions and environmental pollution), saves natural resources and is socially just (UNEP). Even though the principles of resource efficiency, low carbon, social inclusiveness have begun to be developed, they are still unable to overcome human greed to exploit more natural resources. In fact, the implementation of sustainable development with the concept of green products and services, namely environmentally friendly products and services must be purchased at a high price and become increasingly inaccessible to the poor. The weaknesses of the Green Economy Concept include:

Green Economy Concept "Expensive". As mentioned above, environmentally friendly products and services must be purchased at a high price and become increasingly inaccessible to the poor. It takes a greater cost if you want to create something that is good for the environment and humans. What is bad for humans and the environment will be cheap, while on the other hand, things that are good for nature and humans will have a higher price. $100 \%$ organic products of natural origin generally have a high price. For example, paper bags, cloth bags or biodegradable bags have a higher price than ordinary plastic bags. Likewise with the use of solar energy, which requires a nominal subsidy from the government which is not small and sustainable, this will cause the public to pay a larger nominal tax. The Green Economy concept is expensive and not everyone can afford it.

Many Things Are Created And Considered Good For Nature and Humans, But These Are Not So. Many new product breakthroughs were created with the label "environmentally friendly", but not all fit the tagline. For example, bio-soaps are produced using oil produced from oil palm cultivation, whose existence actually destroys the rain forest. Another example is promoting the production of paper bags and cloth bags as a form of limiting the use of plastic bags. In fact, plastic bags were created to save the earth. Thulin (1962) created a durable plastic bag that can be used multiple times as a substitute for paper bags. In those days there was more use of paper bags, meaning more trees were cut and plastic bags were created to reduce the number of trees being cut. The process of returning biodiversity in the form of replanting trees takes a long time.

The Green Economy concept is not completely wrong, but there are several weaknesses as mentioned above that need improvement. That is what underlies the emergence of The Blue Economy Concept, which is to create environmentally friendly business activities based on how nature works and take advantage of what is owned.

According to Jusuf (2012), blue economy can be seen as an action that relies on the comprehensive development of the people's economy in order to achieve overall national development. The principles contained in a green economy, blue economy, and tourism economy can strengthen food and economic security in order to achieve sustainable growth and prosperity for the people (Misbahuddin, 2018).

According to Sutardjo (2012), the principles of a blue economy do not conflict with the concept of a green economy. These two things complement each other because the blue economy is an integral part of the green economy.

\section{METHODS OF RESEARCH}

Researchers used the literature study method, which is an activity to collect data and information through document searches, research reports and scientific publications related to the topic of study. These documents are analyzed by content (content analysis), reviewed and described qualitatively. The indicator that will be observed and measured in this study is the application of the concept of The Blue Economy, especially in the agriculture, fishery and livestock sectors which will eventually manifest in the form of small scale enterprises (MSMEs) in the scale of home industries in Denpasar, Bali. This study uses qualitative descriptive analysis techniques to describe in more detail the application of the concept of 
The Blue Economy as an alternative source of income for the community when turmoil occurs in the tourism sector.

\section{RESULTS AND DISCUSSION}

Overview (Coffee: An Export Crop that Creates Food Security). Prof. Dr. Gunter Pauli, the founder of the concept of The Blue Economy, states that only 0.2 percent of one cup of coffee is actually consumed by the public. The remaining 99.8 percent ends up as waste and is just thrown away. In 2009 an estimated 12 million tonnes of coffee waste were allowed to rot (Pauli, 2012). This coffee waste waste not only produces methane gas which contributes to climate change, but what is even more unfortunate is the loss of a number of economic opportunities and a nominal amount of money wasted. It is a hope that a scientist from Hong Kong, Shuting Chang, has succeeded in finding that coffee waste is an ideal substrate and is suitable for growing tropical fungi such as shiitake and ganoderma mushrooms. This means that millions of tonnes of waste coffee grounds can be reused as a growing medium to make other products which in turn generate cash.

The leftover coffee grounds after harvesting mushrooms can be used as chicken feed considering that mushrooms can break down and decompose fibers which are enriched with essential amino acids and are very popular with livestock such as chickens for example. So coffee grounds waste which has a negative connotation and without added value can be converted into chicken fodder whether it is used in poultry breeding or for domestic chickens at home. Chicken farms will produce meat and eggs which have economic value. So, the application of the concept of The Blue Economy in the context of coffee grounds waste as a medium for growing mushrooms can have multiple positive effects because in addition to producing coffee, this concept also produces mushrooms, chicken meat and chicken eggs. The application of this concept involves the agricultural sector (coffee and mushrooms) and livestock (chicken meat and chicken eggs). This is certainly very good because it is able to create wider employment opportunities.

This discovery is very economic, sustainable and is a positive step for the future. These types of inventions are sustainable solutions for people inspired by the principles of how nature works which has become known as the concept of The Blue Economy. Business activities that apply the concept of The Blue Economy are guided by the workings of nature, namely utilizing the waste generated by an activity which is then used as an input resource for other activities for the purpose of creating new cash flows.

Application Opportunities in Bali Province. The factors that underlie the use of coffee grounds waste as a medium for growing mushrooms are very suitable to be applied in Bali, namely:

1) There is a consumer preference for cholesterol and saturated fat free foods, so that mushrooms can be an alternative choice.

2) The lifestyle of drinking coffee is a trend among the community, especially the millennial generation. This encourages the growth and development of the coffee industry in Indonesia, including in Bali Province. Coffee has changed its image, it is no longer synonymous as a drink among the elderly, now coffee is also the prima donna for young people. In essence, enjoying a cup of coffee has become a tradition for Indonesians when gathering, celebrating, or making friends at work. Coffee sales and marketing techniques are now increasingly developing. Not only available in conventional roadside coffee shops, now coffee shops can also be found in various shopping centers, minimarkets to large malls. Even some minimarkets are now starting to sell coffee drink products under their own brands. In addition, the development of technology has also made coffee shops available for ordering via mobile applications. This business growth is also supported by a variety of coffee shop offerings that are increasingly diverse, such as Grabfood / Gofood, Instagram, Facebook and other social media.

3) Based on data obtained from the International Coffee Organization, it can be seen that Indonesia is the 6th largest coffee consuming country in the world with a range of 4.7 million packs per year. 


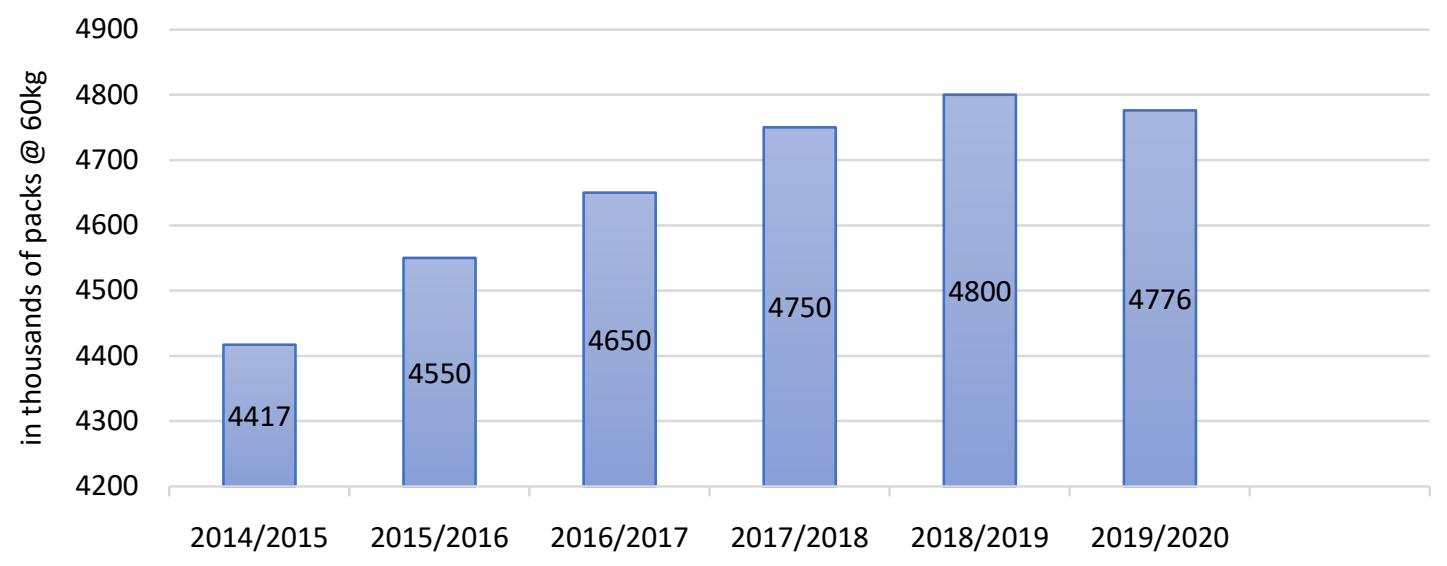

Figure 2 - Coffee Consumption in Indonesia (Source: International Coffee Organization, 31 July 2020)

4) Based on data obtained from the International Coffee Organization, Indonesia is the 4th largest coffee producing country in the world.

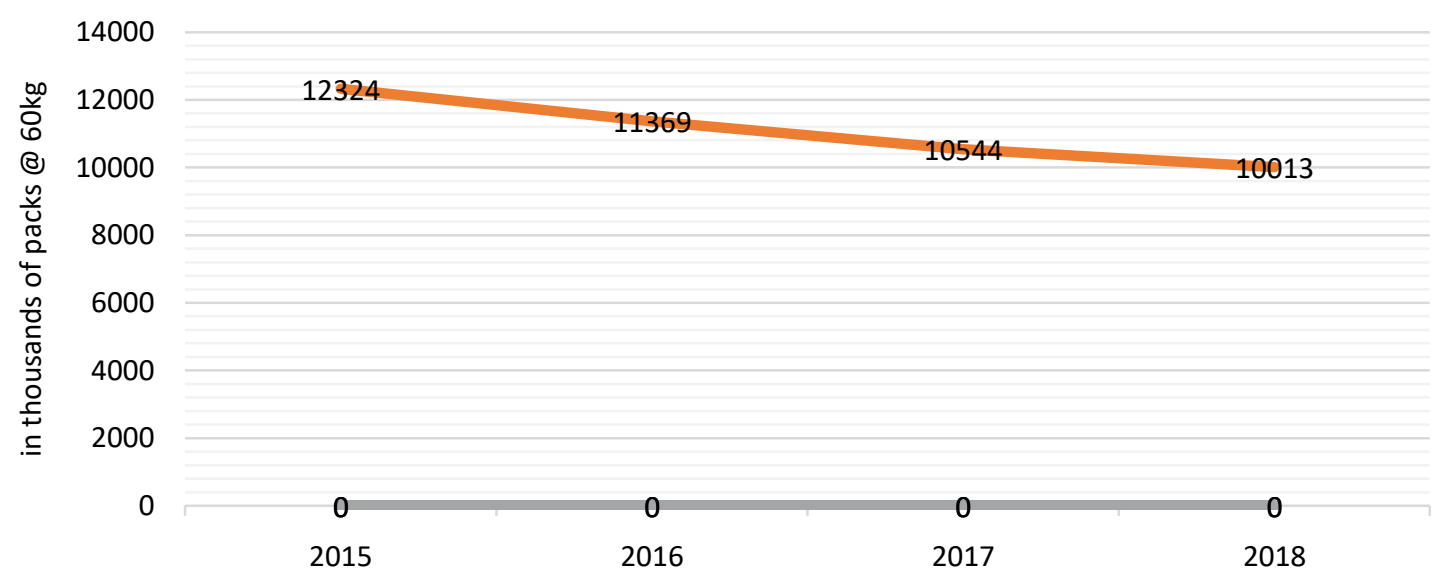

Figure 3 - Coffee Production in Indonesia (Source: International Coffee Organization, 31 July 2020)

5) The Government of Bali, through the Bali Provincial Industry and Trade Office, has been working since 2015 to develop superior agro-industry, one of which is coffee. Efforts made in coffee development include 1) intensifying coffee plants; 2) Rejuvenation of coffee plants, procurement and distribution of assistance to coffee farmers, guidance, control, escort and assistance; 3) Monitoring, evaluation and reporting; and 4) Financing the development of coffee plants. By carrying out this effort, it is hoped that the problems that are detrimental to leading industry in Bali can be resolved and can improve the welfare of coffee farmers in Bali. This proves that the Provincial Government of Bali really cares about the potential of the island's natural resources, namely the coffee plant.

Overview (Integration of Aquaculture into Farming Activities). The conventional combination of livestock activities and farming activities has helped farmers almost all over the world to use manure as fertilizer for crops, and crop residues as feed for livestock. However, most manure generally loses half its nitrogen content before it becomes nitrate and becomes available as fertilizer for crops. So that to produce a product with a greater quantity and improve the quality of the plant, nutrients are needed at a higher price, such as chemical fertilizers and artificial feed. This will result in uneconomical farming activities and will erode small farmers' profits. Professor George Chan, a sanitation engineer, looks back at the precarious and even risky situation in agricultural activities around the world, where poor 
farmers have to work hard to support themselves and try to make a living off the land they own with a few livestock and crops.

A new concept emerged, namely by integrating fish, livestock and farming activities that can help increase the supply of fertilizer and animal feed. The integration of aquaculture into farming and livestock systems has made a very big step forward, not only being able to increase the supply of fertilizers from fish waste, but also increasing people's income from bigger and faster sales of fish and relatively higher market prices. so as to increase income substantially. The cycle is that the nutrients from livestock are used to fertilize the growth of various natural plankton in the pond and then become food for fish. Fish that consume plankton will produce their own waste which is then used to fertilize plants. The real form of applying this concept is the aquaponic system. Meanwhile, in a smaller scale, the home industry is the budikdamber system (fish farming in buckets). This method can be classified as a form of innovation from the concept of The Blue Economy.

Application Opportunities in Bali Province. Utilization of empty yards can actually be developed in the context of realizing food security and household economy. The form of its use can be done by agricultural cultivation and small-scale fisheries. If this is done optimally, it will be able to have a positive impact such as reducing expenses related to the consumption of vegetables and fish, as well as being able to increase household income through the sale of products from the use of these yards (Khomah and Rhina, 2016). One model of yard land use that is able to integrate fish and organic vegetables is the budikdamber system (fish cultivation in buckets). This method is able to produce organic plant and fish products, this happens because the system works, which utilizes algae and food waste and feces produced by fish which will not cause toxic levels in fish ponds but are useful as fertilizer in liquid form for vegetable crops. The need for fertilizer and water is no longer a problem and will reduce production costs. The costs that are cut from this program come from the cost of raw materials and fertilizers as well as labor costs for maintenance. This technique can be carried out by people who live in rural areas and in urban areas by utilizing a small yard area (Susetya and Harahap, 2018). Through this kind of cultivation technique it is also able to strengthen family food security (Perwitasari and Amani, 2019). The application of the budikdamber concept such as catfish farming combined with growing kale vegetables is feasible in Bali. The reason is:

1) Mahayanthi and Ayuningsasi (2015) in their research found that the catfish farming business in Denpasar is categorized as feasible, in terms of the Payback Period and Break Event Point criteria. The return on investment that has been made (Payback Period) is relatively short, namely within a period of eight months. Meanwhile, from the Break Event Point aspect, the average amount of catfish production in Denpasar City per harvest is capable of producing $791 \mathrm{~kg}$, far above the break-even point of $216 \mathrm{~kg}$. The average number of cultivators' production reaches Rp. 11,074,000.00 while the breakeven point of the total production was Rp. 3,029,690.00.

2) Sudana and Suparta (2013) obtained the same results, namely the African catfish farming business in Tabanan Regency is considered feasible, in terms of the Break Event Point aspect in the first year which is shorter than the economic age (5 years).

3) Swaputra, et al (2014) stated that the demand for freshwater fish, including catfish, is quite large for the market in all districts in Bali, especially the demand in Badung Regency and Denpasar City.

4) Based on information from the Bali Province Fisheries Service Public Relations Officer, namely Putu Atmosphere, it is stated that Bali is experiencing difficulties in fulfilling the needs of fish, especially catfish every day. This reason underlies the large supply of catfish from outside Bali, which is twenty tons per day (nusabali.com). This can be an opportunity for the community to cultivate it given the large potential and market share of catfish, especially in Bali.

5) The catfish farming business has promising prospects, apart from its wide market share, due to the existence of a government program, in this case the Bali Provincial Fisheries Service, which is called the Gemarikan program (Movement of the People Eating Fish). This program certainly encourages fish cultivation including catfish. 
6) Suppliers of cultured catfish, which vary from pecel traders, household consumers to collectors. Sometimes due to the large demand, the cultivators are often overwhelmed in fulfilling it.

7) Kale and catfish are relatively easy to cultivate. Kale plants can grow easily and have extraordinary durability. For catfish itself, it has almost the same characteristics, namely that it can survive in conditions of minimal water or even without water, in a narrow space and is able to cram in dozens. Dewa Made Ngurah, Head of the Livestock, Fisheries and Marine Services Office of Denpasar City, said that the development of catfish farming in Denpasar City is very promising because it does not require a lot of land and water (Koran Bisnis Bali, 2013).

8) The selling price of catfish tends to be stable, so it is not something to worry about.

9) Vegetable kale and catfish are unpretentious foods and are available in almost all cities in the archipelago including Bali.

\section{CONCLUSION}

The application of the concept of The Blue Economy, in this case the use of coffee grounds as a medium for growing mushrooms, can have a significant impact on those concerned, the surrounding environment, and the community. This of course is related to converting waste into food, creating food sources for the community, creating wider employment opportunities and at the same time creating new things that have never been applied before by utilizing existing resources by following the workings of nature. An example of using coffee grounds waste as a medium for growing mushrooms can be an inspiration for the Balinese people in particular to create food security and alternative solutions to drive the economic sector that has been hit by the Covid-19 pandemic. It is also capable of being a sustainable solution after the pandemic is over, considering the concept of The Blue Economy is based on responding to basic human needs by utilizing existing resources. This new business concept (creating cash flow from waste products) aims to create wider employment opportunities, increase people's per capita income while still paying attention to the preservation of nature and the environment.

The Integrated Concept of Catfish Cultivation and Kangkung Farming at the Home Industry Scale is a profitable business activity that can be carried out by all levels of society because it is easy and cheap. Increasing the quantity of fish and vegetable production will lead to the fulfillment of household food needs and lead to family food security. This concept is also a very lucrative new business opportunity for the community and as a form of business diversification that is able to create alternative employment opportunities and new sources of income for the community and factory workers who have been laid off, especially in the current Covid-19 pandemic situation.

Suggestions. For further researchers, it is suggested to continue identifying examples of the application of the concept of The Blue Economy and real examples of implementation adapted to the characteristics of each region. This is because the concept of The Blue is able to create alternative employment opportunities, and is able to stimulate a competitive entrepreneurial spirit.

\section{REFERENCES}

1. Ilma, A., F., N. 2014. The Blue Economy: Keseimbangan Perspektif Ekonomi and Lingkungan. Jurnal Ilmu Ekonomi and Pembangunan. Vol. 14 No (1) 2014.

2. Jusuf, Gellwynn (2012). Ekonomi Biru Menjadi Arah Kebijakan Pembangunan Perikanan Siaran Pers Tanggal 6 Juni 2012.

3. Khomah, I and Rhina U. F. (2016). Potensi and Prospek Pemanfaatan Lahan Pekarangan Terhadap pendapatan Rumah Tangga. Proceeding Seminar Nasional Peningkatan Kapabilitas UMKM dalam Mewujudkan UMKM Naik Kelas.155-156

4. Kup. 2013. Agro and Hobi. Koran Bisnis Bali. 23 April 2013.

5. Mahayanthi I, G. A. D., and Ayuningsasi, A. A. K., 2015. E-Jurnal EP Unud. 4 (1) : 57 - 62 
6. Misbahuddin. 2018. Kajian Optimalisasi Potensi Produk Unggulan and Ekonomi Lokal Dengan Prinsip Ekonomi Hijau, Ekonomi Biru, and Ekonomi Pariwisata Kabupaten Majene Provinsi Sulawesi Barat. Jurnal Ilmiah Bisnis and Kewirausahaan. Vol. 7 No 3.

7. Nurhayati, Siti. 2013. "Blue and Economy Policy" And Their Impact to Indonesian Community Welfare. Jurnal Ekonomi and Bisnis. Volume 12. Nomor 01. Maret 2013

8. Pauli, Gunter. 2006. "The Blue Economy, 10 Years, 100 Innovations, 100 Million Jobs". Paradigm Publications

9. Perwitasari DA, Amani T. 2019. Penerapan sistem akuaponik (budidaya ikan dalam ember) untuk pemenuhan gizi dalam mencegah stunting di Desa Gending Kabupaten Probolinggo. Abdi Panca Marga. 1(1): 20-24.

10. Rani, Faisyal., Cahyasari, Wulandari. 2015. Motivasi Indonesia Dalam Menerapkan Model Kebijakan The Blue Economy Masa Pemerintahan Joko Widodo. Jurnal Transasional. Vol. 7, No. 1, Juli 2015.

11. Saksono, Herie. 2013. The The Blue Economy: An Islands Regional Development Solution The Case Study On Anambas Islands Regency. Jurnal Bina Praja. Volume 5 No 1 (2013)

12. Satria, Arif. 2012. Ekonomi Biru. Harian Kompas, Terbitan 15 Desember 2012. Jakarta.

13. Susetya IE, Harahap ZA. 2018. Aplikasi budikdamber (budidaya ikan dalam ember) untuk keterbatasan lahan budidaya di Kota Medan. Abdimas Talenta. 3(2): 416-420.

14. Sutardjo, Sharif C. 2012. Ekonomi Biru Tidak Bertentangan dengan Ekonomi Hijau; Antara, edisi Senin, 25 Juni 2012

15. Swaputra, I., B. Paramarta, W. A., and Nuija, I Nengah. 2014. Aplikasi Tenik Budi Daya Ikan and Manajemen Usaha Untuk Meningkatkan Kesejahteraan Petani Ikan Lele Di Badung-Bali. Majalah Aplikasi Ipteks NGAYAH. Volume 5, Nomor 1.

16. Thulin, Sten Gustaf. 1965. Bag with Handle of Weldable Plastic Material. Assignor to Alrteholaget Celioplast, Norrhopping Sweden.

17. UNEP, "Large Marine Ecosystems Report A Perspective On Changing Conditions In LMEs Of The World's Regional Seas", UN Environment Programme, USA, 2000.

18. Zamroni, A., Nurlaili., and Witomo, Cornelia Mirwantini. 2018. Peluang Penerapan Konsep The Blue Economy pada Usaha Perikanan di Kabutapen Lombok Timur. Buletin IImiah Marina Sosial Ekonomi Kelautan and Perikanan. Vol 4 No 2.

19. Electronic Source: http://www.balipost.com/news/2019/04/08/72497/Erupsi-GunungAgung-dan Ekonomi...html

20. Electronic Source: http://www.balipost.com/news/2020/02/11/103874/Coronavirus-danKetahanan-Ekonomi Bali.html

21. Electronic Source: https://finance.detik.com/berita-ekonomi-bisnis/d-4963358/aduhcorona-jumlah-hotel-yang-tutup-bertambah-jadi-862

22. Electronic Source: https://id.wikipedia.org/wiki/Pandemi

23. Electronic Source: https://tirto.id/yang-janggal-dari-kasus-kematian-pertama-covid-19-diindonesia-eEuP

24. Electronic Source: https://wolipop.detik.com/health-and-diet/d-4946027/apa-yangdimaksud-virus-corona-ini-asal-mula-hingga-gejala-covid-19

25. Electronic Source: https://www.kompasiana.com/mtf3lix5tr/5535a2946ea8347510da42d9/penelitiankualitatif-024-empat-tipe-triangulasi-dalam-pengumpulan-data

26. Electronic Source: https://www.liputan6.com/news/read/443816/efek-bola-salju-bom-bali

27. Electronic Source: https://www.nusabali.com/berita/26994/kebutuhan-tinggi-lele-luarbanjiri-bali

28. Electronic Source: https://www.nusabali.com/berita/67975/bali-harus-cari-andalan-di-luarpariwisata 